\title{
SSynthesis
}

International Scientific Conference of IT and Business-Related Research

\section{ANALIZA IZBORA ODGOVARAJUĆEG SERVOMEHANIZMA UPRAVLJAČKOG SISTEMA MOTORNIH VOZILA}

\section{THE ANALYSIS OF SELECTION OF THE APPROPRIATE POWERED MECHANISM IN THE STEERING SYSTEM OF MOTOR VEHICLES}

\author{
Zoran Majkić \\ Tehnički opitni centar, Beograd, Srbija
}

\begin{abstract}
Apstrakt:
Pri projektovanju vozila teško je precizirati koji je sistem najsloženiji, ali je sigurno da sistem za upravljanje zajedno sa sistemom za kočenje nosi u sebi poseban stepen odgovornosti kada je reč o bezbednosti. Iz toga bi trebalo da proističe odgovarajući stepen važnosti pri projektovanju. U radu se analiziraju otpori zakretanju upravljačkih točkova, prenosni odnosi, sila na volanu u zavisnosti od ugla obrtanja točka upravljača kao osnovni element komfornosti upravljanja motornim vozilom. Data analiza sa prikazom odgovarajućih rezultata ispitivanja i matematičkog modela izrađenog u modulu Simulink programskog paketa Matlab uz primenu odgovarajuće zakonske regulative dovodi do zaključka o izboru odgovarajućeg servomehanizma transportnog automobila formule pogona $6 \times 6$.
\end{abstract}

\section{Ključne reči:}

sila, ugao, volan, servoupravljač, upravljanje.

\section{UVOD}

Upravljački sistem služi za promenu ili održavanje izabranog pravca kretanja vozila i ostvarenja manevrisanja njime. U opštem slučaju upravljački sistem se sastoji iz tri dela: upravljačkog mehanizma, upravljačkog prenos i pojačivača. Servoupravljači se projektuju tako da omoguće lako zakretanje u mestu, ne dovodeći veliku silu upravljačkom točku. Do potrebnih dimenzija sistema za upravljanje, u početnoj fazi izrade projekta, obično se dolazi izvođenjem proračuna njihovog opterećenja pri zakretanju točkova u mestu, pri čemu se moment izračunava empirijski. Dakle, polazna osnova pri projektovanju hidrauličkog servoupravljača jeste odredjivanje momenta otpora zakretanju upravljačkih točkova, a na osnovu čega se odredjuje maksimalna vrednost sile, odnosno momenta na volanu.

\section{MOMENT OTPORA OKRETANJU TOČKOVA U MESTU}

Na veličinu momenta, potrebnog za zaokretanje upravljačkih točkova u mestu utiču:

\section{Abstract:}

When designing a vehicle, it is difficult to identify the most complex system, but it is certain that management system along with the braking system carries a special degree of responsibility in terms of security. It should imply the appropriate level of importance in the design process. The paper analyses resistance to steering wheel rotation, gear ratios, the steering force depending on the angle of rotation of the steering wheel, as the basic element of comfort driving of a motor vehicle. The given analysis with an overview of the results of appropriate tests and mathematical model developed in Simulink module of Matlab with the application of the appropriate legislation, leads to the conclusion on the selection of the appropriate powered mechanism in truck configuration axle $6 \times 6$.

\section{Key words:}

power, angle, steering wheel, power steering, steering.

1. opterećenje na točkovima;

2. koeficijent trenja pneumatika o podlogu;

3. dimenzija i oblik otiska pneumatika o podlogu, koji su odredjeni pritiskom u pneumatiku i njegovom konstukcijom;

4. bočna krutost pneumatika;

5. radijus zaokretanja upravljačkih točkova;

6. uglovi nagiba osovinice ruvakca i nagiba točka;

7. moment trenja u osovinicama rukavca i prenosnom mehanizmu (Gincburg, 1972).

Da bi se ostvarile odgovarajuće vrednosti momenata otpora zakretanju upravljačkih točkova potrebno je voditi računa o svim navedenim relevantnim faktorima, jer time se obezbedjuje manje opterećenje elemenata u sistemu upravljanja, sa jedne strane, a sa druge strane omogućeno je olakšano upravljanje smanjenjem sile, odnosno sile na volanu. Postoji više različitih autora po čijim izrazima je moguće odrediti moment otpora zakretanja, a ovom prilikom biće izdvojeni neki od njih (Janković, 2005). 
MOMENT OTPORA ZAKRETANJA UPRAVLJAČKIH TOČKOVA U MESTU PREMA MINTU

Ukupni moment otpora zakretanja u mestu na obrtnom rukavcu je:

$$
M_{t}=\frac{2}{3} G_{t} \cdot \mu \cdot q \cdot k_{F}
$$

gde su:

$G_{t}$ - vertikalno opterećenje točka;

$\mu$ - koeficijent trenja okretanja pneumatika po podlozi;

$q=\sqrt{a \cdot b}, \mathrm{a}, \mathrm{b}$ - ose elipse otiska pneumatika;

$k_{F}$ - koeficijent, koji uzima u obzir uticaj oblika otikska, a odredjuje se pomoću specijalnog grafika.

Koeficijent $k_{F}$ Mint je dobio samo za jedan pneumatik, pa je korišćenje ove formule praktično nemoguće.

\section{MOMENT OTPORA ZAKRETANJU UPRAVLJAČKIH TOČKOVA PREMA TABOREKU}

$$
M_{t}=\mu^{\prime} \cdot G_{t} \cdot h_{r}
$$

gde je $\mu^{\prime}$ - redukovani koeficijent trenja, koji se određuje u zavisnosti od odnosa radijusa zaokretanja točka (e) i širine pneumatika $(\mathrm{H})($ slika 1$)$

$$
h=\sqrt{\frac{I_{0}}{A_{0}}+\rho^{2}}
$$

gde su:

$I_{0}$ - polarni moment inercije površine otiska pneumatika na podlozi;

$A_{0}$ - površina otiska pneumatika.

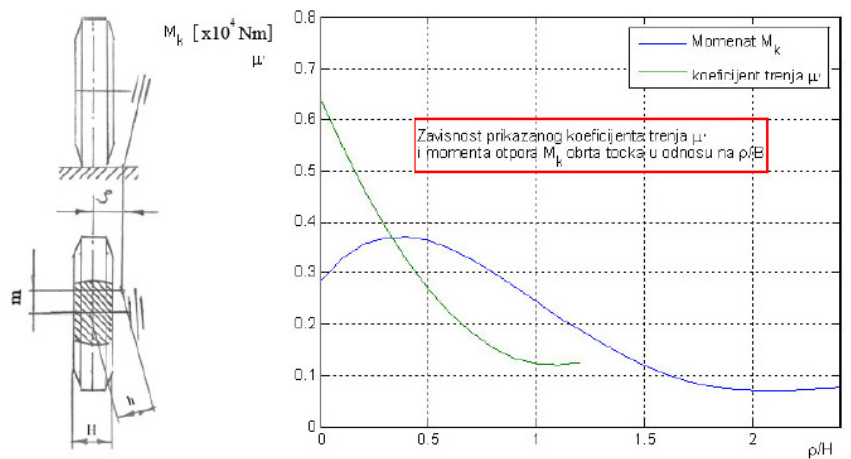

Slika 1. Zavisnost prikazanog koeficijenta trenja $\mu^{\prime}$ i momenta otpora $M_{k}$ obrta točka u odnosu na $\rho / H$ (Gincburg, 1972)

Obično se $I_{0}$ i $A_{0}$ teško određuju pa i ovaj izraz nema nekog praktičnog značaja. U slučaju da je $\mathrm{e}^{2}>\mathrm{I}_{0} / \mathrm{A}_{0}$, što biva kada se projekcija ose osovinice rukavca $A_{0}$ na podlogu nalazi van granica otiska, radijusa inercije $\mathrm{I}_{0} / \mathrm{A}_{0}$ otiska može se zanemariti, pa proizilazi $h=\rho$. Podatci proračuna po ovoj formuli $\mathrm{e}^{2}>\mathrm{I}_{0} / \mathrm{A}_{0}$ potpuno se podudaraju sa eksperimentalnim podatcima.
MOMENT OTPORA ZAKRETANJU UPRAVLJAČKIH TOČKOVA U MESTU PREMA LISOVU

$$
M_{t}=G_{t}\left(0,132 \cdot \mu \cdot R_{t}+f \cdot \rho\right)
$$

gde su:

f - koeficijent otpora kotrljanja točkova;

$\mathrm{R}_{\mathrm{t}}$ - spoljašnji radijus točka;

$\rho$ - krak zaokretanja centra otiska pneumatika, tj. radijus zaokretanja točka.

Ova formula uzima u obzir radijus pneumatika, ali ne uzima u obzir pritisak i elstične karakteristike pneumatika.

\section{MOMENT OTPORA ZAKRETANJU UPRAVLJAČKIH TOČKOVA U MESTU PREMA LITVINOVU}

$$
M_{t}=(0,7 \div 0,75) G_{t} \times \mu \times \frac{\sqrt{A_{0}}}{2}
$$

gde je: $0,7 \div 0,75$ empirijski koeficijent.

Za proračun po ovoj formuli neophodno je znati zavisnost površine otiska pneumatika od opterećenja na njemu.

\section{MOMENT OTPORA ZAKRETANJU UPRAVLJAČKIH TOČKOVA U MESTU PREMA GOUGHU}

$$
\mathrm{M}_{\mathrm{t}}=\frac{\mathrm{G}_{\mathrm{t}}^{3 / 2}}{\mathrm{k} \cdot \mathrm{p}^{1 / 2}}
$$

gde su:

$\mathrm{k}$ - empirijski koeficijent (za obične pneumatike $\mathrm{k}=2,1$ );

$\mathrm{p}$ - pritisak u pneumaticima.

Eksperimentalna istraživanja su pokazala da je ovaj izraz veoma prihvatljiv. Pokušaćemo objasniti koju od prikazanih formula treba koristiti u prvom redu, neophodno je objasniti koji od sedam nabrojanih faktora, koji utiču na veličine momenta, mogu biti poznati pri proračunu. Na točkovima koji se zaokreću obično se unapred zadaju opterećenja i poznata su sa tačnošću $\pm(5-10 \%)$. Koeficijent trenja pneumatika o podlogu (prijanjanje) je poznat i kreće se od 0,7-0,9 za suvu asfaltnu ili betonsku oblogu. Veličina otiska pneumatika zavisi od konstrukcije pneumatika i pritiska u njemu. Prema podatcima (Gincburg, 1972), pri proračunskom opterećenju pneumatika putničkih automobila pritisak na oslonu površinu blizak je pritisku u pneumatiku. Kod pneumatika teretnih automobila površina otiska je veća a pritisak na oslonu površinu je manji, nego što je pritisak u pneumatiku. Pri smanjenju pritiska u pneumaticima ta razlika se smanjuje, a pri povećanju - raste. Pri nominalnom opterećenju krutost pneumatika se malo odražava na njihov pritisak na oslonu površinu. U nedostatku podataka o veličini otiska pneumatika površina otiska se može približno odrediti kao odnos opterećenja i pritiska u pneumatiku. Oblik otiska pneumatika, koji utiče na veličinu polarnog momenta inercije, može se odrediti eksperimentalno. Bočna krutost pneumatika i radijus zaokretanja točka $(\rho)$ pokazuju u određenim granicama mali uticaj na moment otpora zaokretanju. Pri poklapanju centra otiska pneumatika sa centrom zaokretanja točka, moment otpora zaokretanju određuje se izrazom (7): 


$$
\mathrm{M}_{\mathrm{t}}=\mu \cdot \frac{\mathrm{G}_{\mathrm{t}}}{\mathrm{r}_{\mathrm{m}}} \cdot \frac{\mathrm{I}_{0}}{\mathrm{~A}_{0}}
$$

gde je:

$r_{m}$ - maksimalno rastojanje od centra do granice otiska.

Pri pomerenom centru zaokretanja u odnosu na centar kontakta (slika 1) proizilazi ne samo okretanje pneumatika, nego i valjanje točka i pomeranje njegove ravni simetrije prema osnoj liniji otiska. Moment otpora zaokretanju točka u tom slučaju određuje se po formuli:

$$
M_{t}=\mu \frac{G_{t}}{r_{m}} \cdot \frac{I_{0}^{\prime}}{A_{0}^{\prime}}+G_{t} \cdot f \cdot \rho+\frac{c \cdot\left(1-\cos \theta_{p}\right) \cdot\left(l_{0}-\rho \theta_{p}\right) \cdot \rho \cdot m}{l_{0}}
$$

gde su:

$\mathrm{I}_{0}^{\prime}$ - polarni moment inercije površine otiska sa uzimanjem u obzir njegovog smanjenja pri zaokretanju točka za ugao $\theta_{\mathrm{p}}$, pri kome nastaje proklizavanje;

$\mathrm{A}_{0}^{\prime}$ - površina otiska sa uzimanjem u obzir njenog smanjenja pri zaokretanju točka za ugao $\theta_{\mathrm{p}}$;

c - bočna krutost pneumatika, koja dolazi na jedinicu dužine otiska;

$1_{0}$ - dužina osne linije otiska;

m - krak (slika 1.).

Ako se uzme da je oblik otiska pravougaonik, onda pri poznatim karakteristikama pneumatika i parametrima ugrdnje točka nije teško izračunati zavisnost $\mathrm{M}=\mathrm{f}(\rho / \mathrm{H})$. Za realne vrednosti parametara ova zavisnost ima oblik kao na slici 1. Pri $(\rho / H)>1,4-1,6$ momenat $\mathrm{M}$ se smanjuje skoro proporcijalno $\rho$. Pri promeni odnosa $\rho / \mathrm{H}$ od 0 do $0,5-0,7$ moment $M$ nešto se povećava (10-14\%). Tok krive na delu od $(\rho / H)=0$ do $(\rho / H)=0,5$ zavisi od veličine kraka $(\mathrm{m})$ i bočne krutosti pneumatika (c). Što su veličine $(\mathrm{m})$ i (c) veće to više raste vrednost momenta.

\section{REAKTIVNI I CENTRIRAJUĆI ELEMENTI SERVOUREĐAJA}

Upravljački sistem bez servouređaja mora da poseduje jednu vrlo važnu osobinu a to je da razvije sposobnost osećaja kod vozača da oseti praćenje konfiguracije puta, naročito pri kretanju u krivinama (Majkić, 2013). Ovaj osećaj javlja se u tome što se pri povećanju otpora zakretanju upravljačkih točkova pojavljuje i potreba povećanja sile na upravljačkom točku tj.volanu. Ovu osobinu - osećaj puta, mora da poseduje i upravljački sistem sa servouređajem. Da bi se ovo ostvarilo u servouređaj se ugrađuje reaktivni element, čiji je zadatak da vrlo brzo priguše oscilovanje upravljačih točkova pri povratnom uključenju servouređaja (od upravljačkih točkova ka upravljačkom točku - volanu). Vrednost reakcije određuje se na bazi povećanja sile koju treba ostvariti na upravljačkom točku - volanu pri povećanom otporu zakretanja točkova. Kao pokazatelj reaktivnog dejstva koristi se odnos prirasta sile F na volanu sa silama dejstva za svaki prirast sila $\mathrm{F}^{\prime}$ na volanu bez servo dejstva, tj.

$$
\rho=\frac{\Delta \mathrm{F}}{\Delta \mathrm{F}^{\prime}}
$$

Danas su uglavnom poznata tri načina ostvarenja reakcije na upravljačkom točku - volanu i to pomoću:

- reaktivnog ventila;

- reaktivnim plugama;

- reaktivnim elementima.

Jedan od vrlo velikih nedostataka servouređaja jeste njihova sklonst lakog uključivanja pri dejstvu na njih malih sila koje se mogu pojaviti pri kretanju upravljačkih točkova po neravnom tlu. Povratno uključenje na primer kod hidrauličkog servouređaja propraćeno je oscilovanjem upravljačih točkova i "vijuganjem" vozila na drumu. Da bi se sprečila povratna uključivanja servouređaja u sistem se ugrađuje centrirajući element hidrauličnog ili opružnog tipa (jedna ili nekoliko prethodno napregnutih opruga). Dok se neprevaziđe sila kojoj je element za centriranje izložen servouređaj ne može da stupi u dejstvo i upravljački sistem radi kao sistem bez servouređaja. Na ovaj način je ostvarena jedna vrlo važna osobina sistema za upravljanje a to je obezbeđenje stabilnosti kretanja vozila na pravom putu a naročito pri većim brzinama.U cilju obezbeđenja vraćanja upravljačkih točkova elementi za centriranje moraju da budu prednapregnuti silama koje će po vrednosti da budu veće od sile povratnog trenja upravljačkog mehanizma redukovane na sponu razvodnika.

\section{OCENSKI POKAZATEL IZBORA ODGOVARAJUĆEG SERVOMEHANIZMA - SILA NA TOČKU UPRAVLJČA}

Komfornost upravljanja zavisi od sile $\mathrm{F}_{\mathrm{V}}$ koju je potrebno dovesti od strane vozača na upravljački točak (volan) prečnika $\mathrm{R}_{\mathrm{V}}$ da bi se zakrenuli upravljački točkovi. Ta sila ima maksimalnu vrednost pri zakretanju upravljačkih točkova u mestu. Stvarni moment na točku upravljača koji se troši za obrt točka mora da savlada moment otpora odupiranja točka kotrljanju $\mathrm{M}_{1}$, moment odupiranja točka klizanju otiska pneumatika po oslonoj površini $\mathrm{M}_{2}$ i momentom izazvanog stabilizacijom upravljačkog točka $M_{3}$ koji je moguće zanemariti pri odredjivanju maksimalne sile $\mathrm{F}_{\mathrm{vmax}}$.

Moment odupiranja točka kotrljanju jednak je (Лысов, 1972; Majkić, 2012):

$$
\mathrm{M}_{1}=\mathrm{G}_{\mathrm{t}} \cdot \mathrm{f} \cdot \mathrm{a}
$$

gde su:

$G_{t}$ - vertikalno opterećenje točka;

$f$ - koeficijent otpora kotrljanju točka;

$a$ - krak zakretanja točka.

Moment odupiranja točka klizanju jednak je (Лысов, 1972; Majkić, 2012):

$$
M_{2}=0,14 \cdot G_{t} \cdot \phi \cdot r
$$

Uzimajući u obzir, da su na prednjoj osi dva upravljačka točka, moment na rukavcu povezan sa uzdužnom upravljačkom sponom iznosi

$$
M_{R}=2 G_{T}(f \cdot a+0,14 \cdot \phi \cdot r) \cdot \frac{1}{\eta_{i}}
$$

gde je:

$\eta_{i}$ - koeficijenat korisnog dejstva, koji uzima u obzir gubitke na trenje u obrtnim rukavcima i zglobovima upravljačkog prenosa. Pri proračunu preporučuje se vrednost za $\mathrm{f}=0,015$ i $\varphi=0,85$. 


$$
F_{v \max }=M_{R} \cdot \frac{1}{R \cdot i_{\omega}^{\prime} \cdot i_{\omega}^{\prime \prime} \cdot \eta_{D}}
$$

gde su:

$i_{\omega}^{\prime}$ - prenosni odnos upravljačkog prenosa;

$i_{\omega}^{\prime \prime}$ - prenosni odnos upravljačkog mehanizma;

$R$ - radijus upravljačkog točka;

$\eta_{D}$ - direktni koeficijent korisnog dejstva (pri prenosu sile od uprvaljačkog točka ka upravljačkoj poluzi).

Pri kretanju vozila na krivini moment $\mathrm{M}_{2}$ otpora pri klizanju otiska pneumatika mnogo puta je manji nego pri obrtu u mestu i zavisi od brzine kretanja vozila. Na slici 2. prikazana je zavisnost sile na točku upravljača od brzine kretanja vozila. Podatci su dobijeni eksperimentalnim ispitivanjem za transportno vozilo ZIL-585 (Гольд, 1962; Majkić, 2012). Smanjenje sile F $\mathrm{i}_{\mathrm{v}}$ olakšanje upravljanja moguće je povećanjem radijusa upravljačkog točka R, takodje povećanjem prenosnog odnosa upravljačkog mehanizma i' i prenosnog odnosa upravljačkog prenosa $i^{\prime \prime}$, smanjenjem do odredjenih granica kraka zakretanja točka i gubitaka na trenje u obrtnim rukavcima, zglobovima upravljačkog prenosa i u upravljačkom mehanizmu i postavljanjem pojačivača u upravljačkom sistemu. Radijus upravljačkog točka bira se u zavisnosti od morfoloških osobina vozača i preglednosti sa sedišta vozača. On se menja u granicama od $190 \mathrm{~mm}$ (za putnička vozila) do $275 \mathrm{~mm}$ (za teretna vozila veće nosivosti i za autobuse).

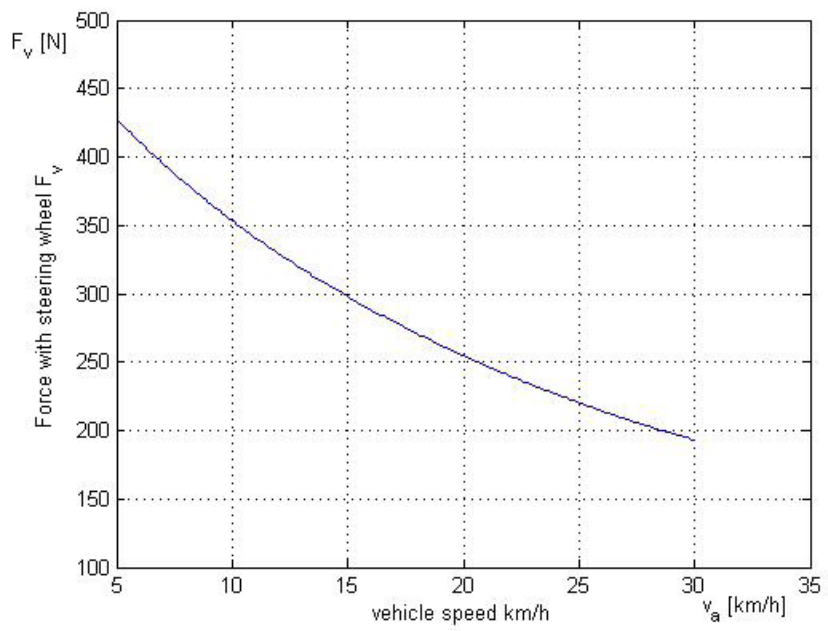

Slika 2. Zavisnost sile na točku upravljača od brzine kretanja vozila Izvor: Гольд (1962); Majkić (2012)

Za meru smanjenja kraka zakretanja točka $a$ otpornost kotrljanju se smanjuje, ali istovremeno raste površinsko trenje izmedju pneumatika i oslone površine. Za pneumatike datog profila, koji poseduju odredjenu elastičnost bitno je neko odredjeno rastojanje $a_{\min }$, pri kome se dobija minimalna sila za obrt vozila. Veličina $a_{\min }$ za projektovano vozilo utvrdjuje se opitnim putem. Uobičajno je $a=30 \div 60 \mathrm{~mm}$. Za teretna vozila veće nosivosti $a=60 \div 100 \mathrm{~mm}$. Prenosni broj upravljačkog mehanizma $i_{\omega}^{\prime}$ za putnička vozila menja se u granicama $12 \div 20$, za teretna vozila i autobuse u granicama $16 \div 32$. Pri povećanju prenosnog broja smanjuje se sila na upravljačkom točku, neophodna za obrt vozila, koja odgovara datom uglu obrta upravljačkog točka. Ako su brža vozila, brže se izvršava obrt njegovih točkova prema tome potreban je manji prenosni odnos upravljačkog me- hanizma. Eksploataciona istraživanja su pokazala, da se dobro manevrisanje vozila obezbedjuje ako se obrt upravljačkih točkova za puni ugao nastaje za 1,0-1,75 (ali ne više od 2,0) obrta upravljačkih točkova u svaku stranu od srednjeg položaja koji odgovara pravolinijskom kretanju. Dakle povoljnija komfornost vozila se dobija variranjem prenosnih odnosa upravljačkog sistema (Гольд, 1962; Majkić, 2012).

$$
i_{\omega}=i_{\omega}^{\prime} \cdot i_{\omega}^{\prime \prime}
$$

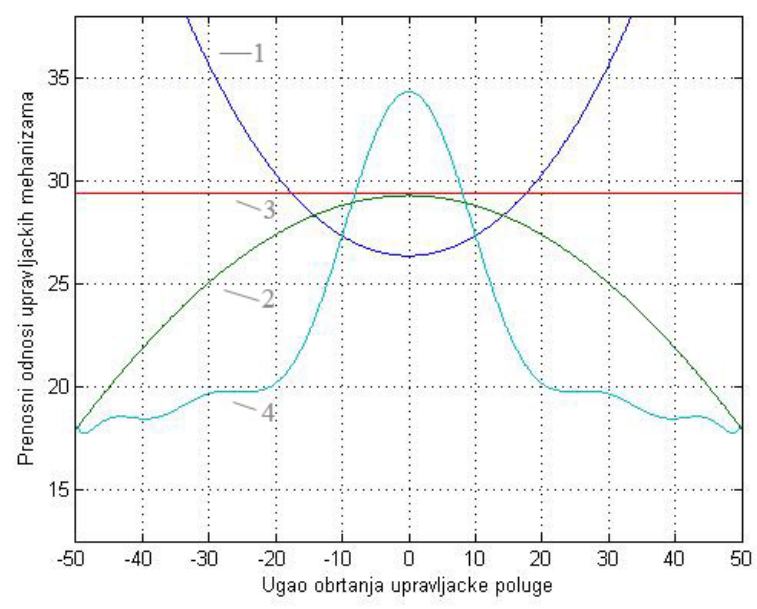

Slika 3. Zavisnost prenosnog odnosa različitih upravljačkih mehanizama u zavisnosti od uglova obrtanja upravljačke poluge.

Izvor: Гольд (1962); Majkić (2012).

Na slici 3. prikazana je promena prenosnih odnosa u zavisnosti od uglova zakretanja upravljačke poluge u levu i desnu stranu. Za putnička vozila različitih tipova upravljački mehanizam je sa konstantnim prenosnim odnosom prava 3 na slici 3 , koja po istraživanjima (Гольд, 1962) zadovoljava eksploatacione zahteve. Kod vozila sa relativno malim brzinama sa većom težinom ponekad imaju prednost mehanizmi sa prenosnim odnosom, koji se menja po krivoj 2, pri blagom zaokretu točka upravljača. Kod vrlo brzih vozila ponekad se primenjuje upravljački mehanizam sa prenosnim odnosom koji se menja po krivoj 1. Za vreme kretanja vozila većim brzinama vozila brzo reaguju pri obrtu upravljačkog točka. Pri naglom zaokretu, koji se obično dešava pri umerenim brzinama kretanja vozila, sila na upravljačkom točku smanjuje se usled povećanja prenosnog odnosa. Smanjenjem gubitaka na trenje i povećanjem direktong koeficijenta korisnog dejstva upravljačkog mehanizma, može se smanjiti rad na upravljačkom točku pri obrtu vozila. Isto značajno povećanje koeficijenta korisnog dejstva upravljačkog mehanizma pri kretanju vozila na neravnom putu može dovesti do toga, da se sve slučajne bočne sile, koje dejstvuju na upravljačke točkove mogu se preneti na upravljački točak što ima za posledicu stvaranja momenta koji treba da prime ruke vozača - rukovaoca što otežava upravljanje vozilom u datim uslovima kretanja. Te okolnosti dozvoljavaju smanjenje koeficijenta korisnog dejstva upravljačkog mehanizma samo do odredjene granice. Koeficijenti korisnog dejstva upravljačkog mehanizma, razlikuju se direktni (pri prenosu sile od upravljačkog točka do upravljačke poluge) i povratni pri prenosu sile od upravljačke poluge do točka upravljača. Čim je veći direktni koeficijent korisnog dejstva tim su manji gubitci u upravljačkom mehanizmu pri obrtu upravljačkih točkova i samim tim više se smanjuje moment na upravljačkom točku pod dejstvom slučajnih bočnih 
sila koje dejstvuju na upravljačke točkove na neravnom putu. Direktni i povratni koeficijent korisnog dejstva uzajamno su povezani. Povratnost upravljačkog mehanizma, koju je moguće oceniti brzinom povratka upravljačkih točkova u položaj koji odgovara pravolinijskom kretanju pri otpuštanju upravljačkog točka i datom zakonu promene stabilizirajućeg momenta biće tim veće čim su manji gubici na trenje u obrtnim rukavcima i zglobovima upravljačkog prenosa. Primenom hidrauličkog servomehanizma olakšavaju se uslovi i povećava se produktivnost rada vozača pored toga poboljšava se i upravljivost, stabilnost vozila pa prema tome povećava se i bezbednost kretanja i brzina manevrisanja u različitim putnim uslovima. Široko su rasprostranjeni hidraulički servomehanizmi kod kojih se zahtevana sila na upravljačkog poluzi obezbedjuje na račun korišćene energije tečnosti. Pred upravljački sistem sa hidroservomehanizmom postavljaju se sledeći zahtevi: visoka brzina dejstva i dobro prateće dejstvo, značajna izlazna snaga neophodna za izvršenje obrta vozila, pouzdanost, stabilnost radnih karakteristika i dr. Maksimalna sila $\mathrm{F}_{\mathrm{vmax}}$ na točku upravljača u otežanim uslovima, sa upravljačkim sistemom sa servo pojačanjem obično se zadaje. Za putnička vozila primenjena sila iznosi $30 \div 50 \mathrm{~N}$ a ponekad i $70 \mathrm{~N}$, za teretna vozila $150 \div 180 \mathrm{~N}$ i za autobuse $140 \div 160 \mathrm{~N}$ (Гольд, 1962).

\section{OPŠTI TEHNIČKI ZAHTEVI ZA SILU NA UPRAVLAČKOM TOČKU METODA ISPITIVANJA}

Zahtevi za maksimalnu silu koja se može dovesti na točak upravljača definisani su u ECE Pravilniku br. 79. Pored navedenog ECE pravilnika postoje i sledeći standardi: Upravljivost i stabilnost vozila opšti tehnički zahtevi Otreslovoj standard OST 37.001.487-89 i standardu GOST R 52302-20004. Metode ispitivanja definisane su Otreslovim standardom OST 37.001.471-88. Ispitivanje se sprovodi na nepokretnom i pokretnom vozilu. Pri kretanju vozila vozilo se kreće brzinom od $10 \mathrm{~km} / \mathrm{h}$. Pri postojanju pojačivača ispitivanje se vrši na minimalnom broju obrtaja motora, pri odsustvu pojačivača sa isključenim motorom. Ugaona brzina obrta upravljačkog točka ne treba da prelazi 60 $\mathrm{o} / \mathrm{s}$. U postupku ispitivanja zapisuju se sledeće vličine: ugao obrta upravljačkog točka $\varphi$, sila na upravljačkom točku $F_{v}$ i vreme obrta $t$.

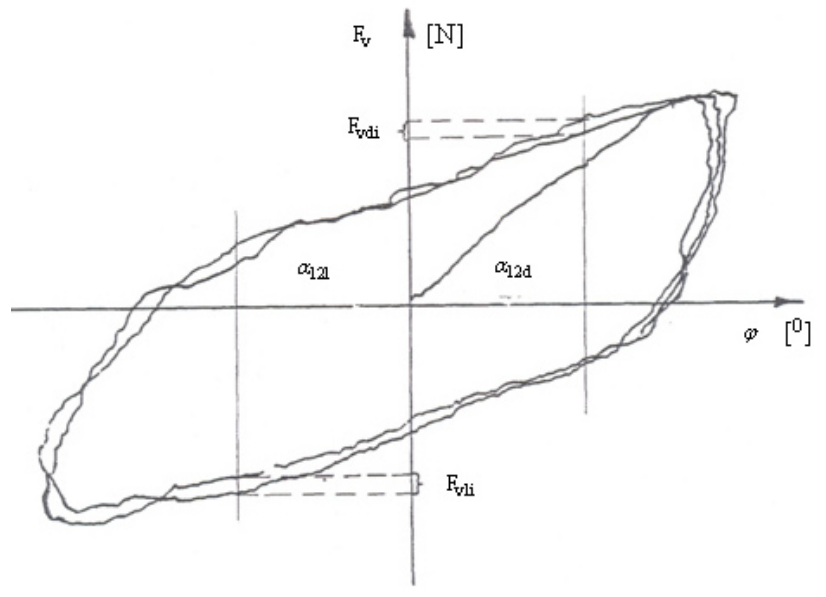

Slika 4. Obrazac zapisa zavisnosti sile na upravljačkom točku od ugla njegovog obrta. (OST 37.001.471-88, 1989)

Izvor: Majkić (2012)
Obrada rezultata predstavlja se dijagramom zavisnosti sile $F_{v}$ na upravljačkom točku od ugla obrta upravljačkog točka $\varphi$ koji se dobija putem transformacije zapisa u vremenu dva navedena parametra. Na slici 4. prikazan je obrazac zapisa zavisnosti sile na upravljačkom točku od ugla njegovog obrta. Na dijagramu su prikazani uglovi obrta upravljačkog točka, koji odgovaraju kretanju prednjeg spoljnjeg točka po krugu $\mathrm{R}=12 \mathrm{~m}$ desno i levo $\varphi_{12 d}$ i $\varphi_{12 l^{\circ}} \mathrm{U}$ intervalu od $\alpha=0$ do $\alpha=\alpha_{12}$, za svaki $i$-ti opit nalazi se maksimalna vrednost sila $\mathrm{F}_{\mathrm{vd}}$ i $\mathrm{F}_{\mathrm{vl}}$, koja se uzima za ocenski pokazatelj. U slučaju da je minimalni radijus obrta vozila na prednjem spoljnjem točku veći od $12 \mathrm{~m}$, vrednost $\mathrm{F}_{\mathrm{vdi}}$ ili $\mathrm{F}_{\mathrm{vli}}$ prelazi $20 \%$, ispitivanja se ponavljaju.

\section{MATEMATIČKI MODEL UPRAVLJAČKOG SISTEMA}

Na slici 5. predstavljen je regulacioni sistem „Vozač - Vozilo (sa servo pojačanjem) - Okolina“ (Urlich et al, 1998). Pošto su međusobne relacije na slici 5 očigledne nema potrebe za daljim detaljnim objašnjenjima.
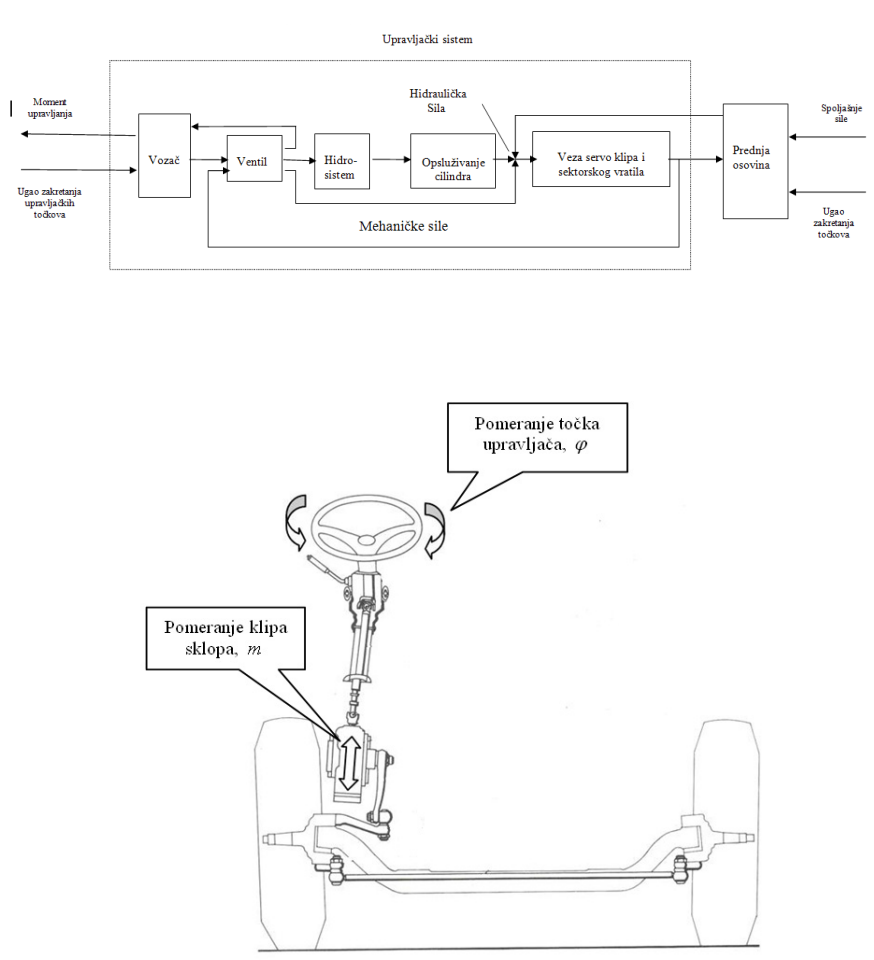

Slika 5. Blok šema: Vozač - Vozilo (sa servopojačanjem) - Okolina (Urlich, et al,1998), mehanički deo sistema za upravljanje

Matematički model upravljačkog sistema koji je predstavljen na slici 6. izrađen je u specijalizovanom modulu Simulink programskog paketa Matlab koji je namenjen za simulaciju dinamike sistema u grafičkom okruženju. Svaki element upravljačkog sistema predstavljen je odredjenim blokom koji sadrži matematički odnos između ulaza i izlaza tog elementa. Promenljive ulaza i izlaza posmatraju se kao signali, a blokovi su povezani orijentisanim linijama koje označavaju tok signala od jednog bloka ka drugom (Urlich et al, 1998; Ćalasan et al, 1996).

Model upravljačkog sistema, sa konstrukcijom upravljačkog mehanizma zupčanik-zupčasta letva sa servopojačanjem, obezbedjuje dobijanje podataka, izlaza pomeranja zupčaste letve u zavisnosti od simuliranog ulaza, zakretanja upravljačkog točka (volana), koji je generisan u obliku jedne sinusoide za 4 s. Pomeranje se dobija izvodjenjem dvostruke integracije ubrzanja 
pomeranja zupčaste letve. U vezi zupčanika - zupčaste letve deluju tri sile: sila trenja stvorena od momenta otpora zakretanju upravljačkih točkova i od momenata trenja u prenosnom mehanizmu, pobudna sila dobivena od momenta generisanog od strane vozača na točku upravljača i sila dobivena od servopojačanja, sa slike 6 se vidi koje su sile pozitivnog, a koje negativnog znaka. Ponašanje servopojačanja opisano je matematičkom formulom. Modelu ovog sistema dat je period od $4 \mathrm{sec}$ za ulazno upravljanje sa sve većom magnitudom koja je 0 kada je $t=0$, i postiže 1 radijan $\mathrm{za} t=10 \mathrm{sec}$.

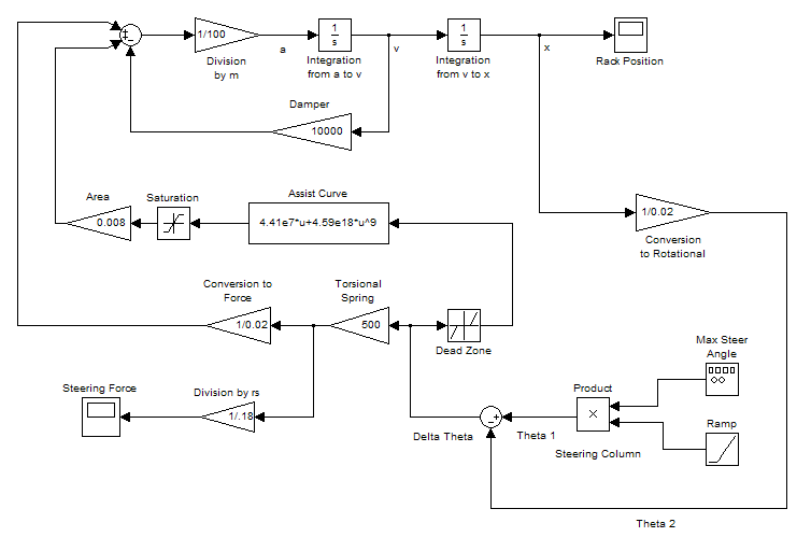

Slika 6. Model hidraučičkog upravljačkog sistema

Pri uključenoj hidraulici maksimalna sila na točku upravljača je 12,28 N. Sa isključenom hidraulikom maksimalna sila na točku upravljača iznosi $35 \mathrm{~N}$.

Isključenje servo - pojačanja, ono se dobija na taj način što se u izradjeni model unosi da je površina klipa jednaka nuli.
Iz dobivenih rezultata pomeranja zupčaste letve, vidi se da u prikazanim pomeranjima nema razlike sa i bez servopojačanja, što odgovara stvarnom stanju, razlika je u momentu zakretanja upravljačkih točkova odnosno uloženoj sili na točku upravljača.

\section{VERIFIKACIJA IZBORA ODGOVARAJUĆEG SERVOUPRAVLJAČA}

Verifikacija izbora odgovarajućeg servoupravljača obavljena je na konstrukciji terenskog automobila formule pogona $6 \times 6$. Korišćen je hidraulički servoupravljač sa otklonom upravljačke poluge od $96^{\circ}$ pri 6,1 obrta točka upravljača, i sa prenosnim odnosom 22,7:1. Po kriterijumu ECE 79 za vozilo kategorije N2 predvidjena je maksimalna sila od $250 \mathrm{~N}$ na obimu točka upravljača pri ulasku vozila brzinom $10 \mathrm{~km} / \mathrm{h}$ iz pravca u krivninu radijusa $20 \mathrm{~m}$ u vremenu od 4 sec., u slučaju havarije servosistema sila na obimu točka upravljača ne treba da bude veća od $350 \mathrm{~N}$. Za nepokretno vozilo maksimalna sila na točku upravljača sa uključenim servopojačivačem iznosi $180 \mathrm{~N}$ dok sa isključenim servopojačivačem iznosi $350 \mathrm{~N}$. Rezultati ispitivanja predstavljeni su na slikama 11,12 i 13 . Sa slike 11 se vidi da je maksimalna momenat na točku upravljača $327 \mathrm{Nm}$ što odgovara sili od 90 $\mathrm{N}$ a što je manje od gornje dozvoljene granice od $250 \mathrm{~N}$. Iz prikazanih rezultata vide se da je sila pri obrtanju točka upravljača u levu stranu $73 \mathrm{~N}$.

$\mathrm{Na}$ slici 11 predstavljeni su podatci dobijeni pri ispitivanju sile na točku upravljača, upravljanje u mestu. Sa slike 12 vidi se da je pri kretanju bez uključenog servomehanizma maksimalni moment na točku upravljača $320 \mathrm{~N}$ koji se ostvaruje pri 2,1 obrta točka upravljača, što je manje od $350 \mathrm{~N}$. Na slici 13 predstavljeni su podatci dobijeni pri ispitivanju sile na točku upavljača (vožnja bez hidraulike).

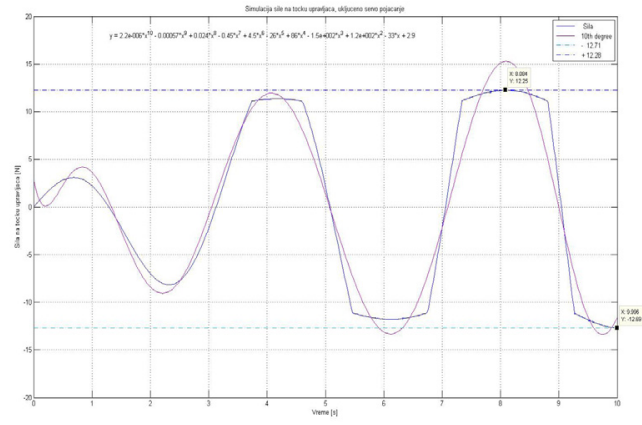

Slika 7. Sila na volanu sa uključenim servo pojačanjem

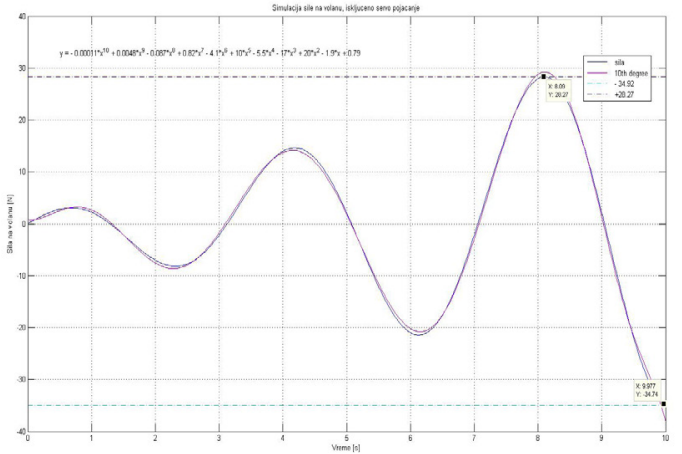

Slika 9. Simulacija sile na volanu, isključeno servo pojačanje

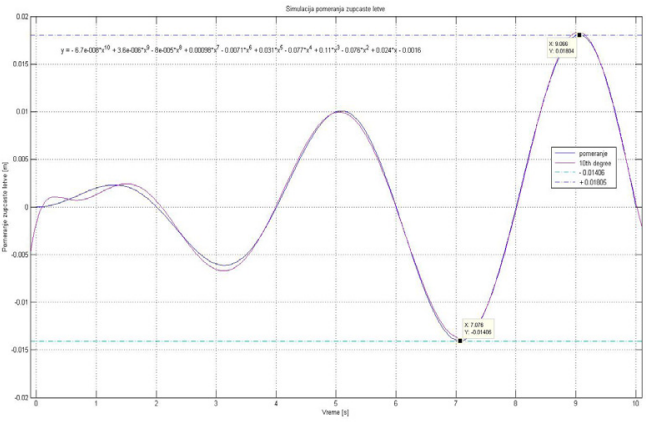

Slika 8. Pomeranje zupčaste letve sa uključenim servo pojačivačem

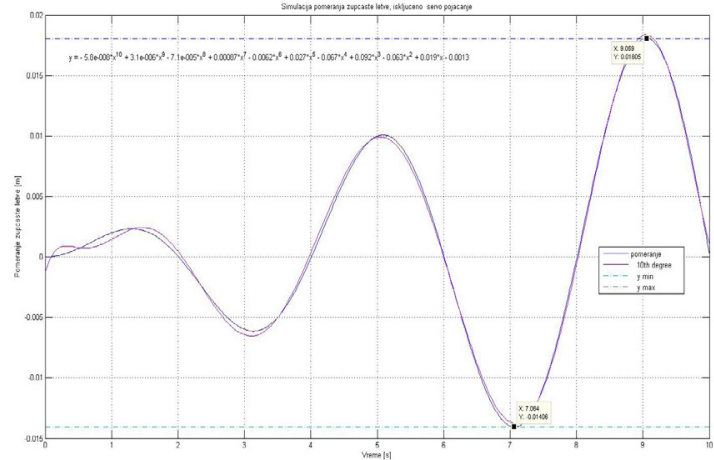

Slika 10. Simulacija pomeranja zučaste letve, isključeno servo pojačanje 


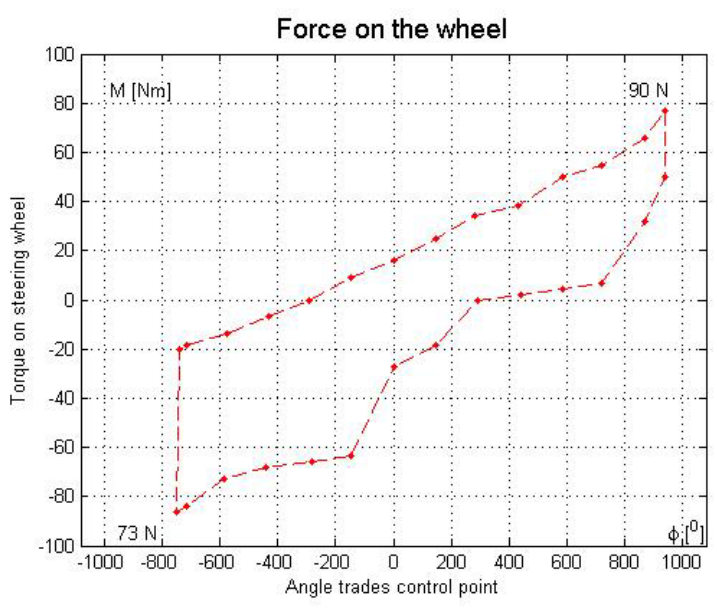

Slika 11. Promena momenta na točku upravljača (brzina $8-10 \mathrm{~km} / \mathrm{h}$ ) Izvor: Minić $(1992,2012)$

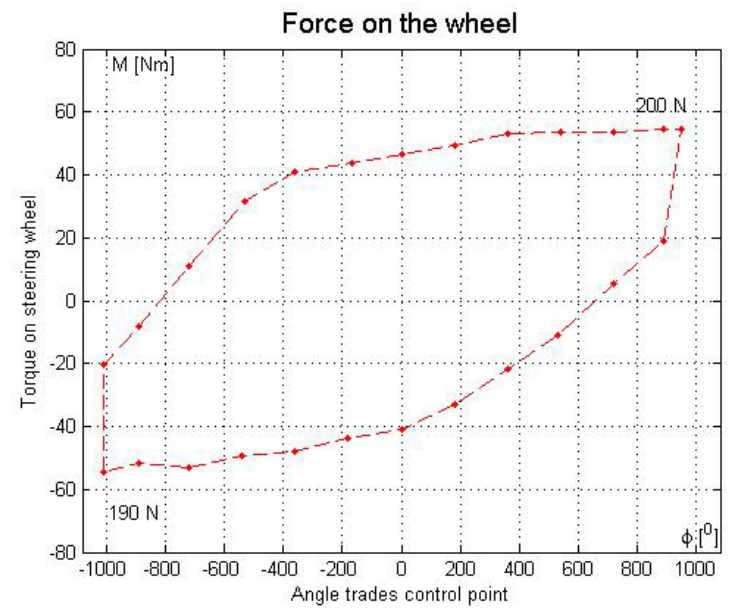

Slika 13. Sila na točku upravljača, sa servopojačanjem, obrtanje u mestu

Izvor: Minić (1992), Majkić (2012)

Sa slike 13 se vidi da je maksimalna sila pri obrtanju točka upravljača u mestu sa uključenom hidraulikom iznosi $200 \mathrm{~N}$, što odgovara 2,63 obrta točka upravljača. Po kriterijumu dobijena vrednost izlazi izvan dopuštene vrednosti za $20 \mathrm{~N}$.

\section{ZAKLJUČAK}

Projektovanjem upravljačkog sistema motornih vozila određuju se osnovni parametri njegovih elemenata i sklopova, obezbeđujući ostvarenje postavljenih zahteva upravljanja vozilom. Osnovni ulazni podatak pri projektovanju servomehanizma je određivanje momenta otpora zakretanju upravljačkih točkova. Da bi se ostvarile odgovarajuće vrednosti momenta otpora zakretanju upravljačkih točkova potrebno je voditi računa o navedenim uticajnim faktorima, jer time se obezbeđuje manje opterećenje elemenata u sistemu upravljanja sa jedne strane, a sa druge strane omogućeno je olakšano upravljanje smanjenjem momenta odnosno sile na volanu. U ECE Pravilniku br. 79 definisana je maksimalna sila koja se može dovesti na točak upravljača, o ovom parametru sistema za upravljanje prilikom razvoja vozila treba vodi računa. Hod klipa i dužina hidocilndra određuju se za maksimalne uglove obrta upravljačkih točkova i za komponovanu šemu hidrocilindra u okviru upravljačkog siste-

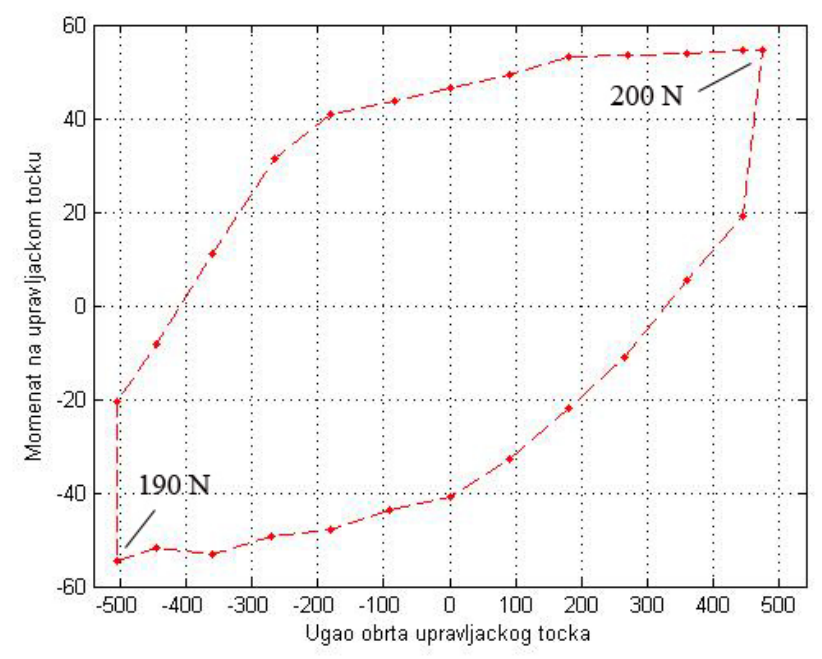

Slika 12. Promena momenta na točku upravljača (brzina $8-10 \mathrm{~km} / \mathrm{h}$ )

Izvor: Minić (1992), Majkić (2012)

ma vozila, nakon toga određuje se prečnik klipa hidrocilindra. Sklonost povratnom uključenju hidropojačivača, bio bi narušen osnovni zahtev koji se postavlja pred upravljački sistem a to je vraćanje upravljačkih točkova po izlasku iz krivolinijskog u položaj pravolinijskog kretanja pod dejstvom stabilizirajućeg momenta. Da bi se sprečilo povratno uključenje u servopojačivač se ugrađuje reaktivni i centrirajući element. Prednapregnutošću centralnih opruga obezbeđuje se vraćanje volana i upravljačkih točkova, pod dejstvom stabilizacionog momenta bez uključenja pojačivača. Sila trenja u upravljačkom mehanizmu mora biti manja od sile prednaprezanja centralnih opruga $F_{n}$. Pravilno projektovani pojačivač mora da obezbedi da zbirni momenat od izvršnog cilindra i vozača premaši moment otpora u čitavom dijapazonu uglova zakretanja točkova. Prikazana analiza je pokazala da do smanjenja sile na točku upravljača moguće je doći povećanjem ugaonog prenosnog odnosa upravljačkog mehanizma, smanjenjem nepotrebnih gubitaka na trenje u njemu i povećanjem njegovog koeficijenta korisnog dejstva smanjenjem kraka obrta upravljačkih točkova i primenom pojačivača. Dovoljno veliki ugaoni prenosni odnos upravljačkog mehanizma je faktor koji dozvoljava u značajnom stepenu smanjenje sile na točku upravljača za vreme obrta vozila. Obzirom na prikazane rezultate ispitivanja sile na točku upravljača u zavisnosti od njegovog ugla obrta može se izvući zaključak da odabrani hidraulički servomehanizam odgovara datom transportnom vozilu formule pogona $6 \mathrm{X} 6$.

\section{LITERATURA}

Гинцбург, Л. (1972). Гидравлические усилители рулевого управления автомобилей. Машиностроение (Mašinostroenie), Moskva.

Heisler, H. (2002). Advanced Vehicle Technology. Oxford: Butterwoeth-Heinemann.

Janković, D. (2005). Momenti otpora zakretanju upravljanih točkova. Monografija povodom 30 godina (1975-2005), str. 8796. Kragujevac: Mašinski fakultet.

Ćalasan, L., \& Petkovska, M. (1996). MATLAB i dodatni moduli Control System Toolbox i SIMULINK. Beograd: Mikro knjiga.

Majkić, Z. (2012). Analysis of judgmentsf indicators for comfort management of transportation vehicles. Proceedings of the 5th International Scientific Conference on Defensive Technologies OTEH 2012. 
Majkić, Z. (2013). Projektni proračun hidrauličkog servoupravljača upravljačkog mehanizma motornih vozila. Vojnotehnički glasnik, 61(3), 141-158. DOI:10.5937/vojtehg61-2017

Mathworks. (2012). Matlab. Preuzeto 7, aprila 2012 sa http:// www.mathworks.com

Minić, M. (1992). Sistemi za upravleojanje teretnih vozila: teorija, proračun, konstrukcija, ispitivanje. Beograd: ABC glas.

OST 37.001.471-88 (1989). Управлямость и устойчивость автотранспортных средств. Метод испытаний. Москва.

OST 37.001.487-89. (1991). Управляемость и устойчивость автомобилей. Общие технические требования. Москва.

Regullation No 79. (2005). Uniform Provisions Concerning the Approval of Vehicles with regard to Steering Equipment, United Nations.

Reimpell, J., Stoll, H., \& Betzler, J. (2001). The Automotive Chassis. Oxford: Butterwoeth-Heinemann.
Urlich, H., Boeker, M., \& Ketl, R. (1998). Simulationen zur optimierung von servolenkungen. Internationales Fluid technisches Kolloquium, Aachen.

Бухарин, Н.А., Прозоров В.С., \& Щукин, М.М. (1973). Автомобили: Констукция, Нагрузочные режимы, Рабочие процессы, Прочность агрегатов автомобиля, Машиностроение, Ленинград.

Гольд, Б.В. (1962). Конструирование и расчет автомобиля. Moskva: Машгиз.

ГОСТ Р52302-2004. (2005). Автотранспортние средства. Управляемость и устойчивость. Технические требования. Методы испытаний. Москва.

Лысов, И.М. (1972). Рулевые управления автомобилей. Машиностроение (Mašinostroenie), Moskva. 